\title{
EFEKTIFITAS PIJAT TUI NA TERHADAP KENAIKAN BERAT BADAN BALITA USIA 1 - 2 TAHUN
}

\author{
The Effectiveness Of The Tui Na Massage On Increase \\ Toddler's WeightAge 1-2 Years \\ Titik Wijayanti $^{1}$, Ardiani Sulistiani ${ }^{2}$ \\ STIKES Estu Utomo \\ (titikeub.tw@gmail.com)
}

\begin{abstract}
ABSTRAK
Latar Belakang : Pada tahun 2015 prevalensi balita yang memiliki berat badan dibawah garis merah KMS (Kartu Menuju Sehat) di Boyolali sebanyak 0,9\% atau sebanyak 546 balita dan di wilayah Puskesmas Musuk terdapat 14 kasus balita mengalami gizi kurang atau sekitar 0,02 \% (Dinas Kesehatan Boyolali, 2015). Banyak faktor yang mempengaruhi kejadian gizi kurang antara lain faktor herediter dan faktor lingkungan. Pemerintah telah melakuka berbagai upaya untuk menurunkan atau mencegah kejadian gizi kurang pada balita, diantaranya dengan stimulasi pertumbuhan. Termasuk dalam stimulasi pertumbuhan adalah stimulasi/ rangsangan yang berupa pijat bayi salah satunya adalah Pijat Tui Na yang dapat meningkatkan kelancaran peredaran darah limfa dan sistem pencernaan yang berdampak pada peningkatan penyerapan asupan nutrisi sehingga dapat meningkatkan berat badan (Sukanto, 2010). Dengan dilakukan Pijat Tui Na akan membantu anak balita dalam meningkatkan nafsu makan sehingga berat badan juga meningkat dengan demikian dapat membantu menurunkan angka kejadian balita dengan berat badan rendah atau tudak sesuai umur.

Tujuan : Tujuan dari penelitian ini adalah untuk mengetahui efektivitas pijat Tui $\mathrm{Na}$ terhadap kenaikan berat badan balita usia $1-2$ tahun.

Metode : Penelitian ini merupkan penelitian eksperimen semu atau quasi experiment designs, dengan rancangan one group pretest-postest dengan perlakukan Pijat Tui Na, sebelum memberikan Pijat Tui Na diawali dengan pengukuran berat badan anak (pre test), setelah diberikan Pijat Tui Na sebanyak 6x berturut - turut dalam seminggu diakhiri dengan pengukuran berat badan anak kembali (post test) 1 bulan kemudian. Sampel diambil dengan tehnik purposive yang memenuhi kriteria balita dengan berat badan kurang berdasarkan umur atau nafsu makannya sulit sehingga didapatkan jumlah sampel sebanyak 20 balita.Metode yang digunakan dalam pengumpulan data adalah observasi, dengan intrumen ceklist pijat Tui $\mathrm{Na}$ dan lembar observasi, sedangkan analisis data menggunakan Paired t test.

Hasil : Hasil analisis data dengan Paired $t$ testmenunjukkan bahwa nilai $\rho$-value $(0,000)$ $<\alpha(0,05)$ maka Ho ditolak dan Ha diterima artinya Pijat Tui Na efektif meningkatkan berat badan balita.

Simpulan : Setelah dilakukan pijat Tui Na sebagian besar balita mengalami kenaikan berat badan artinya Pijat Tui Na efektif meningkatkan berat badan balita. Dengan demikian pijat Tui Na dapat lebih dikenalkan kepada tenaga kesehatan dan keluarga agar diterapkan pada balita dengan berat badan atau nafsu makan yang kurang.
\end{abstract}

Kata kunci : Pijat Tui Na, Kenaikan Berat Badan Balita 


\begin{abstract}
Background : In 2015 the prevalence of children under five who were under the red line of KMS (Card Towards Healthy) in Boyolali was as much as $0.9 \%$ or as many as 546 toddlers and in the Pusuk Puskesmas area there were 14 cases of under-fives experiencing under nutrition or around $0.02 \%$ (Health Office Boyolali, 2015). Many factors that influence the incidence of malnutrition include hereditary factors and environmental factors. The government has made various efforts to reduce or prevent the incidence of malnutrition in infants, including stimulation of growth. Included in growth stimulation is stimulation / stimulation in the form of baby massage one of which is Tui Na Massage which can increase the smooth circulation of lymph blood and the digestive system which has an impact on increasing absorption of nutrient intake so that it can increase body weight (Sukanto, 2010). By doing Massage Tui Na will help toddlers in increasing appetite so that weight also increases so that it can help reduce the incidence of toddlers with low weight or not according to age.

The Aim : The purpose of this study was to determine the effectiveness of Tui $\mathrm{Na}$ massage on increasing weight for toddlers aged 1-2 years. 1

Method :The research used is quasi-experimental designs, with the design of one group pretest-posttest with Tui Na Massage treatment, before giving Tui Na Massage begins with the measurement of the child's weight (pre test), after being given 6 times Tui Na Massage - participating in the week ends with a measurement of the child's weight back (post test) 1 month later. Samples were taken with purposive techniques that met the criteria of toddlers with less weight based on age or difficult appetite, so that the number of samples was 20 toddlers. The method used in data collection is observation, with instruments to check Tui $\mathrm{Na}$ massage and observation sheets, while data analysis using Paired t test. Result :The results of data analysis with Paired t test showed that the value of $\rho$ value $(0,000)<\alpha(0,05)$ then Ho was rejected and Ha was accepted meaning Massage Tui Na effectively increased the weight of toddlers.

Conclusion : After a Tui Na massage, most toddlers gain weight, meaning Massage Tui Na effectively increases toddler weight. Thus Tui Na massage can be introduced to health workers and families so that it is applied to toddlers with weight or lack of appetite.
\end{abstract}

Keywords: Tui Na Massage, Increase Toddler's Weight

\title{
PENDAHULUAN
}

Masa balita merupakan masa/periode yang sangat penting dalam proses tumbuh kembang manusia. Pertumbuhan dan perkembangan pada masa balita menjadi penentu keberhasilan pertumbuhan dan perkembangan anak di periode berikutnya. Masa tumbuh kembang di usia balita merupakan masa yang berlangsung cepat dan tidak akan pernah terulang, karena itu sering disebut 
golden age atau masa keemasan. Setiap orang tua menginginkan anaknya tumbuh dengan normal. Pertumbuhan (growth) yaitu berkaitan dengan masalah perubahan dalam besar jumlah, ukuran atau dimensi tingkat sel, organ maupun individu, yang bisa diukur dengan ukuran (gram, pound, kilogram) ukuran panjang $(\mathrm{cm}$, meter), umur tulang dan keseimbangan metabolik/ retensi kalsium dan nitrogen tubuh. Pertumbuhan dan perkembangan dipengaruhi berbagai faktor diantaranya faktor herediter dan faktor lingkungan. (Soetjiningsih,2010). Apabila faktor tersebut tidak terpenuhi dengan baik dapat menyebabkan gangguan pertumbuhan yang salah satu indikatornya adalah kenaikan berat badan yang tidak sesuai dengan umur anak.

Di Indonesia pada tahun 2017 terdapat 17,8 \% balita yang mengalami masalah gizi, dimana 9,8\% termasuk kategori kurus dilihat dari BB/U (Depkes RI,, 2017). Sedangkan di Jawa Tengah pada tahun 2017 terdapat 12,6 \% balita yang mengalami masalah gizi (Dinkes Jawa Tengah, 2017) Data yang diperoleh dari Dinas Kesehatan Kabupaten Boyolali menunjukkan, pada tahun 2015 prevalensi balita yang memiliki berat badan dibawah garis merah KMS (Kartu Menuju Sehat) sebanyak 0,9\% atau sebanyak 546 balita. (Dinas Kesehatan Boyolali, 2015).

Berbagai upaya pemerintah dilakukan untuk mengurangi dan mencegah terjadinya masalah gizi pada balita sejak dalam masa kehamilan sampai masa balita itu sendiri antara lain pemberian Fe 90 tablet selama kehamilan, vitamin A 2x/ tahun, PMT, penimbangan rutin, serta stimulasi pertumbuhan dan perkembangan. (Soetjiningsih,2010). Diantara stimulai pertumbuhan yang saat ini mulai banyak digunakan adalah pijat bayi. Salah satu jenis pijat bayi yang mulai banyak dilakukan untuk meningkatkan nafsu makan anak yang pada akhirnya dapat meningkatkan berat badan anak adalah pijat Tui Na. Pijat Tui Na ini merupakan tehnik pijat yang lebih spesifik untuk mengatasi kesulitan makan pada balita dengan cara memperlancar peredaran darah pada limpa dan pencernaan, melalui modifikasi dari akupunktur tanpa jarum, teknik ini menggunakan penekanan pada titik meridian tubuh atau garis aliran energi sehingga relatif lebih mudah dilakukan dibandingkan akupuntur (Sukanta,2010). Apabila kesulitan makan teratasi maka asupan gizi bayi terpenuhi dengan baik sehingga berat badan dapat meningkat.

Pijat Tui Namerupakanteknik pijat menggunakan tangan dan penerapan tekanan pada titik pijat untuk meredakan gejala, mengobati penyakit, atau membantu memulihkan kesehatan pasien (Hapsari, TA, 2013).

Pijat Tui $\mathrm{Na}$ ini merupakan tehnik pijat yang lebih spesifik untuk mengatasi kesulitan makan pada balita dengan cara memperlancar peredaran darah pada limpa dan pencernaan, melalui modifikasi dari akupunktur tanpa jarum, teknik ini menggunakan penekanan pada titik meridian tubuh atau garis aliran energi sehingga relatif lebih mudah dilakukan dibandingkan akupuntur.(Sukanta, 2010).

Pada balita dengan berat badan yang kurang dengan pijat Tui $\mathrm{Na}$ akan membuat peredaran darah di limfa dan sistem pencernaan menjadi lebih lancar sehingga nafsu makan bertambah dan penyerapan nutrisi/ gizi lebih optimal akibatnya dapat meingkatkan berat badan. (Sukanta, 2010). 


\section{METODE PENELITIAN}

Penelitian yang digunakan adalah penelitian eksperimen semu atau quasi experiment designs, dengan rancangan one group pretest-postest. Dimana dalam penelitian ini akan dilakukan pretest sebelum diberikan perlakuan berupa penimbangan berat badan serta akan dilakukan posttest setelah diberikan perlakuan. Bentuk perlakukan di sini adalah Pijat Tui Na. Populasi dalam penelitian ini adalah seluruh balita di wilayah BPM Ardiani S, kecamatan Musuk, kabupaten Boyolali. Adapun sampel dalam penelitian ini balita usia $1-2$ tahun dengan berat badan tidak sesuai umur sejumlah 20 balita. Tehnik sampling yang digunakan adalah Purposive Sampling.

Pengumpulan data dilakukan dengan observasi menggunakan timbangan dan lembar observasi. Untuk analisis data ada 2 jenis yaitu analisis univariat untuk mengetahui distribusi frekuensi dan analisis bivariat dengan paired t test. Sebelum dilakukan analisis bivariat dilakukan dulu uji normalitas data dengan Shapiro wilk dan uji homogenitas dengan One Way Annova. Setelah semua data terkumpul, akan dilakukan uji prasyarat analisi terlebih dahulu yaitu uji normalitas dengan rumus Shapiro-Wilk dikarenakan jumlah sampel kurang dari 200 dimana data dapat dikatakan normal apabila probabilitas (sig) $>0,05$. Berdasarkan hasil perhitungan dengan SPSS didapatkan hasil nilai probabilitas (sig) adalah 0,219> 0,05 artinya data penelitian berdistribusi normal.

Selanjutnya data juga akan diuji homogenitasnya dengan rumus One Way Anova dimana data dapat dikatakan homogen/ sama apabila nilai signifikansinya $>0,05$. Berdasarkan hasil perhitungan dengan SPSS didapatkan hasil nilai signifikansi adalah $0,711>0,05$ artinya varian data penelitiannya homogen/ sama.

\section{HASIL DAN PEMBAHASAN}

Tabel 1 Distribusi Frekuensi Berat Badan Setelah Dilakukan Pijat Tui Na

\begin{tabular}{cccc}
\hline No & Berat Badan & Frekuensi (f) & Prosentase (\%) \\
\hline 1 & Naik & 19 & 95 \\
2 & Turun & 0 & 0 \\
3 & Tetap & 1 & 5 \\
& Total & $\mathbf{2 0}$ & $\mathbf{1 0 0}$ \\
\hline
\end{tabular}

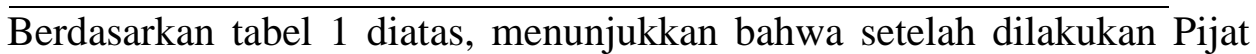
Tui Na sebagian besar balita mengalami kenaikan berat berat badan sebanyak 19 balita $(95 \%)$ dan ada 1 balita $(5 \%)$ yang tidak mengalami kenaikan berat badan atau tetap.

Tabel 2 Analisis Rata - Rata Kenaikan Berat Badan Bayi Pre - Post Pijat Tui Na

\begin{tabular}{lccccc}
\hline \multicolumn{5}{c}{ Paired Samples Statistics } \\
\hline \multirow{4}{*}{ Pair 1 } & Mean & $\mathrm{N}$ & Std. Deviation & Std. Error Mean \\
& Prestest & 8.4950 & 20 & .88703 & .19835 \\
& Posttest & 10.7850 & 20 & .95492 & .21353 \\
\hline
\end{tabular}

Berdasarkan tabel 2 diatas menunjukan bahwa terdapat kenaikan rata rata berat badan bayi setelah dilakukan pijat Tui $\mathrm{Na}$ sebesar 2,29. 
Tabel 3 Analisis Bivariat Paired t test Efektivitas Pijat Tui Na terhadap Kenaikan Berat Badan Bayi Usia 1 - 2 tahun

\begin{tabular}{ccccc}
\hline \multicolumn{4}{c}{ Paired Samples Correlations } \\
\hline & N & Correlation & Sig. \\
Pair 1 & Prestest \& Posttest & 20 & .984 & .000 \\
\hline
\end{tabular}

Berdasarkan tabel 3 diatas menunjukkan bahwa nilai korelasi t-test sebesar 0,984 dengan angka signifikansi 0,000 dimana $\alpha=5 \%=0.005$ sehingga $0,000<0,005$ yang artinya ada pengaruh antara pijat Tui $\mathrm{Na}$ terhadap kenaikan berat badan balita, yang artinya pula bahwa pijat Tui $\mathrm{Na}$ efektif meningkatkan berat badan balita. Nilai korelasi 0,984 menunjukkan bahwa pijat Tui Na berkaitan sangat erat terhadap kenaikan berat badan balita.

Berdasarkan tabel 1 diatas, menunjukkan bahwa setelah dilakukan Pijat Tui $\mathrm{Na}$ sebagian besar balita mengalami kenaikan berat berat badan serta ada yang tidak mengalami kenaikan berat badan atau tetap. Salah satu jenis pijat bayi yang mulai banyak dilakukan untuk meningkatkan nafsu makan anak yang pada akhirnya dapat meningkatkan berat badan anak adalah pijat Tui Na. Pijat Tui Na ini merupakan tehnik pijat yang lebih spesifik untuk mengatasi kesulitan makan pada balita dengan cara memperlancar peredaran darah pada limpa dan pencernaan, melalui modifikasi dari akupunktur tanpa jarum, teknik ini menggunakan penekanan pada titik meridian tubuh atau garis aliran energi sehingga relatif lebih mudah dilakukan dibandingkan akupuntur (Sukanta,2010). Apabila kesulitan makan teratasi maka asupan gizi bayi terpenuhi dengan baik sehingga berat badan dapat meningkat. Pada berat badan tetap ini dikarenakan nafsu makan anak tetap kurang karena anak baru terkena diare. Hal ini sesuai teori Soetjiningsih, 2010 bahwa pertumbuhan anak salah satunya dipengaruhi oleh lingkungan biologis yaitu penyakit kronis, dimana penyakit dapat mempengaruhi metabolisme tubuh dalam penyerapan makanan.

Berdasarkan tabel 2 dan 3 diatas menunjukkan terjadi peningkatan nilai ratarata pre test (berat badan awal) dan post test (berat badan setelah dilakukan pijat Tui $\mathrm{Na}$ ) sebesar 2,29 dan nilai Sig.(2-tailed) $0,00<\alpha(0,05)$ yang artinya ada pengaruh antara pijat $\mathrm{Tui} \mathrm{Na}$ terhadap kenaikan berat badan balita, yang artinya pula bahwa pijat Tui $\mathrm{Na}$ efektif meningkatkan berat badan balita. Nilai korelasi 0,984 menunjukkan bahwa pijat Tui Na berkaitan sangat erat terhadap kenaikan berat badan balita.

Pijat Tui $\mathrm{Na}$ merupakan teknik pijat menggunakan tangan dan penerapan tekanan pada titik pijat untuk meredakan gejala, mengobati penyakit, atau membantu memulihkan kesehatan pasien (Hapsari, TA, 2013).Pijat Tui Na ini merupakan tehnik pijat yang lebih spesifik untuk mengatasi kesulitan makan pada balita dengan cara memperlancar peredaran darah pada limpa dan pencernaan, melalui modifikasi dari akupunktur tanpa jarum, teknik ini menggunakan penekanan pada titik meridian tubuh atau garis aliran energi sehingga relatif lebih mudah dilakukan dibandingkan akupuntur (Sukanta,2010).

Dengan pijat Tui $\mathrm{Na}$ yang merupakan salah satu teknik untuk melepaskan nyeri dan meningkatkan mobilitas tubuh dengan cara melancarkan sirkulasi darah, tubuh akan mendapatkan lebih banyak zat gizi yang membantu proses pemulihan 
bagian yang terluka atau terasa nyeri. Pijatan juga bersifat menenangkan karena mengendurkan otot-otot yang tegang, khususnya pada bagian punggung atas, leher, dan pundak.Pada balita dengan berat badan yang kurang dengan pijat Tui $\mathrm{Na}$ akan membuat peredaran darah di limfa dan sistem pencernaan menjadi lebih lancar sehingga nafsu makan bertambah dan penyerapan nutrisi/ gizi lebih optimal akibatnya dapat meningkatkan berat badan. (Sukanta, 2010).

Hasil penelitian ini juga didukung oleh penelitian lain yang menyebutkan bahwa pijat Tui $\mathrm{Na}$ efektif meningkatkan nafsu makan dan berat badan balita. (Wahyuningrum, DA, 2017). Penelitian lain yang mendukung adalah bahawa pijat Tui Na efektif mengatasi kesulitan makan pada balita dengan cara memperlancar peredaran darah ke limpa dan pencernaan sehingga dapat juga membantu meningkatkan berat badan balita dengan nilai siginfikansi $\rho(0,009)<\alpha(0,05)$. (Munjinah, A. 2015).

\section{Simpulan}

\section{SIMPULAN DAN SARAN}

Sebagian besar balita mengalami kenaikan berat berat badan sebanyak 19 balita $(95 \%)$ dan ada 1 balita $(5 \%)$ yang tidak mengalami kenaikan berat badan atau tetap. Rata - rata kenaikan berat badan balita setelah dilakukan pijat $\mathrm{Tui} \mathrm{Na}$ adalah 2,29. Pijat Tui $\mathrm{Na}$ efektive meningkatkan berat badan balita (nilai $\rho$-value $(0,00)<\alpha(0,05))$ dengan korelasi yang erat $(0,984)$.

\section{Saran}

BPM dapat melakukan pijat Tui Na untuk semua balita dengan masalah berat badan atau nafsu makan yang kurang. Bagi keluarga dapat meningkatkan partisipasi anggota keluarga dalam melaksanakan pijat Tui Na.

\section{DAFTAR PUSTAKA}

Dinkes Boyolali. Profil Kesehatan Kabupaten Boyolali. 2015.Boyolali : Dinas Kesehatan.

Depkes RI. Profil Kesehatan Indonesia . 2017.Jakarta : Departemen Kesehatan.

Dinkes Propinsi Jawa tengah.Profil Kesehatan Jawa Tengah. 2017. Semarang : Dinas Kesehatan.

Hapsari, TA, 2013. Pijat Tui Na Meningkatkan Nafsu Makan dan Memperlancar Metabolisme pada Tubuh Balita.Available from :www.docdoc.com. Diunduh pada tanggal 07 Januari 2018

Mundjinah, A. 2015. Efektifitas Pijat Tui Na Dalam Mengatasi Kesulitan Makan Pada Balita Di RW 02 Kelurahan Wonokromo Surabaya. Jurnal Ilmiah Kesehatan Vol. 8, No. 2 Agustus 2015, hal : 193 - 199.

Soetjiningsih. 2010.Tumbuh Kembang Anak. Jakarta : EGC.

Sukanta, P. Okta.2010.Akupressur \& Minuman untuk Mengatasi Gangguan Kesehatan Reproduksi. Jakarta: PT Elex Media Komputindo.

Wahyuningrum, DA. 2017. Efektifitas Pijat Tui Na Dalam Meningkatkan Nafsu Makan Pada Balita Usia 1 - 5 Tahun di BPM Ma'rifatun MS Puring. Karya Tulis Ilmiah Prodi DIII Kebidanan STIKES Muhammadiyah Gombong. 